\title{
PELUANG KERJA LULUSAN PENDIDIKAN EKONOMI FAKULTAS EKONOMI UNIVERSITAS NEGERI YOGYAKARTA
}

\author{
Aula Ahmad Hafidh, Tejo Nurseto, Ali Muhson, dan Supriyanto \\ Fakultas Ekonomi Universitas Negeri Yogyakarta \\ email: aula_hsf@uny.ac.id
}

\begin{abstract}
Abstrak: Peluang Kerja Lulusan Pendidikan Ekonomi Fakultas Ekonomi Universitas Negeri Yogyakarta. Tracer study ini bertujuan untuk mengetahui masa tunggu, persebaran, dan tingkat relevansi pekerjaan Jurusan Pendidikan Ekonomi FE UNY. Penelitian ini merupakan penelitian deskriptif eksploratif dengan pendekatan kuantitatif. Populasi penelitian ini adalah alumni Prodi Pendidikan Ekonomi FE UNY lulusan tahun 2007 sampai dengan tahun 2016. Sampel diambil secara convenience sampling. Pengumpulan data dilakukan dengan menggunakan teknik angket, dokumentasi dan wawancara. Analisis data menggunakan analisis deskriptif. Penelitian ini menemukan bahwa (1) masa tunggu lulusan untuk mendapatkan pekerjaan pertama termasuk dalam kategori cepat; (2) peluang kerja lulusan terbesar untuk pekerjaan pertama masih didominasi oleh pegawai swasta, tenaga pengajar/tentor, dan guru swasta; (3) relevansi lulusan dengan pekerjaan yang ditekuni saat ini tergolong cukup baik; dan (4) kinerja lulusan termasuk dalam kategori baik.
\end{abstract}

Kata kunci: peluang kerja, masa tunggu, persebaran pekerjaan, relevansi pekerjaan

\begin{abstract}
Job Opportunity of Economics Education Gratitude in Faculty of Economics, State University of Yogyakarta. This study was aimed at determining the postpone period, distribution, and the level of relevance between the job and the Department of Economic Education FE UNY. This research is an explorative descriptive research with quantitative approach. The population of this research was the alumni of FE UNY Economic Education Program from 2007 to 2016 . The samples were taken by convenience sampling. The data were collected using questionnaires, documentation and interviews. The data were analyzed using descriptive analysis. The results show that (1) the postpone period for graduates to get the first job is relatively fast; (2) the largest job opportunities for the first graduate are still dominated by private employees, teachers/mentors, and private teachers; (3) the relevance of graduates with current occupations is quite good; and (4) the performance of graduates is relatively good.
\end{abstract}

Keywords: job opportunity, postpone period, job distribution, job relevance 


\section{PENDAHULUAN}

Pengangguran selalu menjadi isu penting dalam sebuah proses pembangunan. Dari sisi ekonomi, pengangguran merupakan produk dari ketidakmampuan pasar kerja dalam menyerap angkatan kerja yang tersedia. Ketersediaan lapangan kerja yang relatif terbatas, tidak mampu menyerap para pencari kerja yang senantiasa bertambah setiap tahun seiring dengan bertambahnya jumlah penduduk. Tingginya angka pengangguran tidak hanya menimbulkan masalah-masalah di bidang ekonomi, melainkan juga menimbulkan berbagai masalah dibidang sosial, sepertikemiskinan dan kerawanan sosial. Data tentang situasi ketenagakerjaan merupakan salah satu data pokok yang dapat menggambarkan kondisi perekonomian, sosial, bahkan tingkat kesejahteraan penduduk di suatu wilayah dan dalam suatu waktu tertentu atau kurun waktu tertentu.

Masalah tenaga kerja menyangkut banyak aspek dan sifatnya menyeluruh, serta merupakan isu nasional yang mempunyai implikasi kebijakan. Data Badan Pusat Statistik (BPS) menunjukkan bahwa tingkat pengangguran terbuka pada Februari 2016 mencapai 7,02 juta orang atau 5,5 persen. Walaupun jumlah pengangguran tersebut menurun bila dibandingkan dengan Februari 2015, yang mencapai 7,45 juta orang $(5,81$ persen), namun tingkat pengangguran lulusan universitas malah meningkat dari 5,34 persen menjadi 6,22 persen (Tempo, 2016). Kondisi tersebut menunjukkan bahwa tantangan dunia pendidikan khususnya perguruan tinggi menjadi semakin berat. Perguruan tinggi yang diharapkan mampu menghasilkan lulusan yang kreatif dan inovatif dalam menciptakan peluang kerja, ternyata tidak mampu terserap dalam dunia kerja.
Pendidikan sebagai human investment merupakan salah satu sasaran pokok pemerintah dalam upaya meningkatkan kesejahteraan rakyat. Melalui human investment, seseorang atau lembaga dapat meningkatkan nilai pasar (market value) dari pekerja terdidik. Seseorang atau institusi mendanai investasi pendidikan bagi pekerja dengan harapan agar pekerja tersebut lebih produktif, relatif terhadap biaya untuk mendanai pendidikan. Manusia terdidik adalah pelaku ekonomi produktif yang secara riil maupun potensial mampu memacu produktivitas industri. Oleh karena itu, semakin banyak manusia terdidik, semakin banyak pekerja yang produktif, dan semakin produktiflah kinerja ekonomi nasional.

Saat ini kritikan tajam yang diarahkan ke pendidikan tinggi adalah ketidakpuasan sebagian masyarakat terhadap kinerja perguruan tinggi. Perguruan tinggi cenderung hanya berorientasi pada menghasilkan lulusan (product oriented) tetapi belum memikirkan bagaimana penyerapannya dalam dunia kerja (market-oriented). Harapan masyarakat, perguruan tinggi harus sudah berjalan berdasarkan pada market-oriented atau malahan harus sudah siap melangkah pada tahapan society-oriented, mengingat iklim kompetisi semakin menghangat di era globalisasi. Pada kedua tahapan itu perguruan tinggi harus memfokuskan manajerial organisasinya pada kepuasan pelanggan, yang terdiri masyarakat pengguna (user), masyarakat intelektual, dan masyarakat peminat pendidikan (calon mahasiswa). Oleh sebab itu keluwesan dan keleluasaan sistem kerja, budaya dan struktur perguruan tinggi perlu dievaluasi dan diperbaiki.

Sekarang sudah saatnya menyiapkan peserta didik melalui pendidikan dengan pola, konsep, dan model baru yang dapat mengembangkan kepribadian. Pendidik- 
an harus membantu pengembangan peserta didik dalam konsep life skill yang menyiapkan peserta didik agar memiliki kecakapan hidup yang bermakna dan berguna di kemudian hari. Dengan adanya orientasi, paradigma, dan sistem pendidikan yang baru, diharapkan dapat mengatasi masalah pengangguran yang saat ini merupakan salah satu dari berbagai masalah ketenagakerjaan di Indonesia.

Berbagai cara telah diupayakan oleh pemerintah melalui dunia pendidikan, di antaranya dengan dikembangkannya pendidikan yang bercirikan keterkaitan dan kesepadanan (link and match) dan dikembangkannya pendidikan berbasis kompetensi. Cara-cara tersebut menunjukkan bahwa pendidikan yang dilaksanakan harus sesuai dan sepadan dengan kebutuhan dunia kerja, sehingga keterserapan lulusan oleh dunia kerja menjadi tinggi. Oleh karena itu, pendidikan harus memperhatikan kompetensi yang ada pada dunia kerja untuk dikembangkan dalam pembelajaran, sehingga siswa memiliki kompetensi seperti harapan dunia kerja. Dengan demikian, pendidikan saat ini harus berorientasi pada kompetensi yang dibutuhkan oleh dunia kerja atau dunia usaha.

Untuk menganalisis ketenagakerjaan, secara garis besar penduduk suatu negara dibedakan menjadi dua golongan, yaitu tenaga kerja (penduduk yang telah berusia 10 tahun atau lebih) dan bukan tenaga kerja (penduduk yang usianya kurang dari 10 tahun). Tenaga kerja selanjutnya dipilah ke dalam dua kelompok, yaitu angkatan kerja dan bukan angkatan kerja. Kusnendi (2003: 6-4) menyatakan bahwa angkatan kerja adalah penduduk dalam usia kerja atau tenaga kerja yang bekerja, atau mempunyai pekerjaan namun untuk sementara sedang tidak bekerja dan yang mencari pekerjaan. Bukan angkatan kerja adalah tenaga kerja atau penduduk dalam usia kerja yang tidak bekerja dan sedang tidak mencari pekerjaan, yang terbagi dalam tiga kelompok yaitu penduduk dalam usia kerja yang sedang bersekolah, mengurus rumah tangga dan penerima pendapatan lain/pensiunan maupun penyandang cacat.

Untuk mengatasi masalah pengangguran, dikembangkanlah pendekatan pemanfaatan penggunaan tenaga kerja. Pendekatan labor utilization approach (pemanfaatan penggunaan tenaga kerja) menitikberatkan pada aspek penggunaan tenaga kerja dilihat dari jumlah jam kerja, produktivitas, dan pendapatan/upah yang diperoleh (Kusnendi, 2003: 6.6).

Asumsi dasar teori human capital adalah bahwa seseorang dapat meningkatkan penghasilannya melalui peningkatan pendidikan. Hubungan pendidikan dengan produktivitas kerja dapat tercermin dalam tingkat penghasilan. Pendidikan yang lebih tinggi mengakibatkan produktivitas kerja yang lebih tinggi dan oleh sebab itu memungkinkan penghasilan yang lebih tinggi juga (Simanjuntak, 1998: 74).

Pendidikan adalah salah satu sarana untuk meningkatkan kualitas SDM. Untuk meningkatkan efektivitas dan efisiensi penyelenggaraan pendidikan, perlu ditingkatkan kualitas manajemen pendidikan. Berkaitan dengan masalah ini, Engkoswara (2001: 5) menyebutkan bahwa "Manajemen pendidikan yang diharapkan menghasilkan pendidikan yang produktif, yaitu efektif dan efisien, memerlukan analisis kebudayaan atau nilai-nilai dan gagasan vital dalam berbagai dimensi kehidupan yang berlaku untuk kurun waktu yang cukup di mana manusia hidup".

Walaupun semakin tinggi pendidikan seseorang, bukan berarti jaminan untuk memperoleh pekerjaan akan semakin mudah (Citradewi \& Margunani, 2016). 
Namun demikian, peningkatan kualitas pendidikan tepat penting dilakukan. Kualitas pendidikan dapat dilihat dari nilai tambah yang dihasilkan oleh lembaga pendidikan, baik produk dan jasa maupun pelayanan yang mampu bersaing di lapangan kerja yang ada dan yang diperlukan. Peningkatan kualitas SDM dapat dilakukan melalui peningkatan kualitas pendidikan. Pendidikan akan mempunyai kontribusi terhadap ekonomi jika lulusan pendidikan semestinya memiliki kemampuan dan keterampilan yang relevan dengan tuntutan dunia kerja. Dengan demikian semakin tinggi kualitas lulusan yang dihasilkan diharapkan semakin cepat memperoleh pekerjaan.

Penelitian Kobstan (2005) menemukan bahwa jenis kelamin tidak mempengaruhi seseorang dalam memperoleh pekerjaan, sedangkan usia, tingkat pendidikan, status pernikahan, kompetensi/keahlian yang dimiliki mempengaruhi seseorang dalam memperoleh pekerjaan. Temuan ini menunjukkan bahwa kecepatan seseorang untuk memperoleh pekerjaan lebih ditentukan oleh pendidikan dan kompetensi yang dimiliki.

Pekerjaan adalah suatu rangkaian tugas yang dirancang untuk dikerjakan oleh satu orang dan sebagai imbalan diberikan upah dan gaji menurut kualifikasi dan berat-ringannya pekerjaan tersebut. Adapun jenis pekerjaan adalah kumpulan pekerjaan yang mempunyai rangkaian tugas yang bersamaan. Jenis pekerjaan dalam Klasifikasi Baku Jenis Pekerjaan Indonesia (KBJI) adalah kumpulan pekerjaan yang cukup bersamaan tugas utamanya sehingga bisa digabungkan bersama dalam satu kelompok dalam keseluruhan sistem klasifikasi (BPS, 2014).

BPS membagi klasifikasi pekerjaan didasarkan pada tingkat dan spesialisasi keahlian. Tingkat keahlian yang diperlukan suatu jenis pekerjaan ditentukan berdasarkan luas dan kompleksitas dari rangkaian tugas. Makin luas dan kompleks rangkaian tugas-tugas, makin tinggi tingkat keahlian yang diperlukan untuk jenis pekerjaan tersebut. Tingkat keahlian secara operasional diukur dengan jumlah tahun pendidikan formal, pelatihan dan pengalaman yang relevan yang biasanya diperlukan untuk bisa menyelesaikan rangkaian tugas secara memuaskan. Di sini kriteria tentang pelatihan tidak diberlakukan secara eksplisit. Adapun spesialisasi keahlian dari suatu jenis pekerjaan merupakan fungsi dari bidang pengetahuan yang diperlukan, peralatan dan perlengkapan yang dipakai, bahan mentah serta barang dan jasa yang diproduksi sehubungan dengan tugastugas jenis pekerjaan.

Klasifikasi jenis pekerjaan menurut KBJI 2014 terbagi ke dalam (1) Tentara Nasional Indonesia (TNI) dan Kepolisian Negara Republik Indonesia (POLRI); (2) Manajer; (3) Profesional; (4) Teknisi dan Asisten Profesional; (5) Tenaga Tata Usaha; (6) Tenaga Usaha Jasa dan Tenaga Penjualan; (7) Pekerja Terampil Pertanian, Kehutanan dan Perikanan; (8) Pekerja Pengolahan, Kerajinan, dan yang berhubungan dengan itu; (9) Operator dan Perakit Mesin; (10) Pekerja Kasar.

Peluang kerja atau biasa disebut dengan kesempatan kerja selalu menjadi sasaran pembangunan nasional, khususnya di pembangunan bidang ekonomi. Job opportunity is the perceived availability of alternative jobs in the labor market which are as good as or better than the current job (Yoon, Han, \& Seo, 1996). Kesempatan kerja sebagai suatu keadaan di mana semua pekerja yang ingin bekerja pada suatu tingkat upah tertentu akan dengan mudah mendapat pekerjaan (Sukirno, 2000: 68). Menurut Disnakertrans, 
kesempatan kerja adalah banyaknya orang yang dapat tertampung untuk bekerja pada suatu perusahaan atau suatu instansi (www.nakertrans.go.id). Dengan demikian dapat dikatakan bahwa peluang kerja atau kesempatan kerja mencerminkan jumlah dari total angkatan kerja yang dapat diserap atau ikut secara aktif dalam kegiatan perekonomian. Pengertian tersebut jika dikaitkan dengan lulusan yang dihasilkan sebuah perguruan tinggi dapat diartikan bahwa peluang kerja adalah banyaknya lulusan yang mampu terserap dalam dunia kerja.

Beberapa penelitian tracer study di perguruan tinggi menemukan bahwa secara keseluruhan ada kesesuaian antara profesi yang ditekuni dengan bidang keahlian yang dimiliki (Dewojati, dkk., 2002; Herlinah, 2000; Mulyadi; 2006). Beberapa tracer studi yang dilakukan di Prodi Pendidikan Ekonomi FE UNY menemukan bahwa tingkat relevansi dilihat dari jenis pekerjaan termasuk kategori cukup, sementara itu jika dilihat dari mata pelajaran yang diampu juga sangat relevan (Muhson, dkk., 2012), tingkat keterserapan lulusan termasuk sangat tinggi namun relevansi lulusan dengan pekerjaan yang ditekuni saat ini tergolong kurang (Wahyuni, dkk., 2014), dan masa tunggu untuk mendapatkan pekerjaan pertama cukup cepat (Sumardiningsih, dkk., 2016).

Guna mendukung keberlanjutan program tracer study, penelitian ini bertujuan untuk mengetahui waktu tunggu, persebaran, dan tingkat relevansi pekerjaan lulusan Jurusan Pendidikan Ekonomi FE UNY. Penelitian ini penting untuk dilakukan karena akan menghasilkan informasi bagi penyediaan database alumni. Database tersebut sangat diperlukan sebagai bahan untuk penyusunan borang akreditasi prodi sekaligus sebagai masukan untuk mengevaluasi kinerja jurusan. Hasil penelitian ini diharapkan memberikan informasi yang bermanfaat bagi pengelola pendidikan, khususnya Jurusan Pendidikan Ekonomi Fakultas Ekonomi Universitas Negeri Yogyakarta dalam pengembangan dan menentukan kebijakan tentang manajemen jurusan, pengembangan kurikulum, dan peningkatan proses pembelajaran.

\section{METODE}

Penelitian ini termasuk dalam jenis deskriptif eksploratif, yaitu penelitian yang berusaha mendeskripsikan suatu gejala, peristiwa, kejadian yang terjadi pada saat sekarang. Dengan kata lain, penelitian deskriptif mengambil masalah atau memusatkan perhatian kepada masalah-masalah aktual sebagaimana adanya pada saat penelitian dilaksanakan (Sudjana, 2004: 64).

Penelitian ini dilaksanakan di Yogyakarta dan sekitarnya, atau menyesuaikan dengan domisili responden lulusan Jurusan Pendidikan Ekonomi FE UNY. Variabel yang diteliti meliputi waktu tunggu lulusan, jenis pekerjaan, tingkat relevansi, dan kinerja. Waktu tunggu lulusan adalah lama waktu yang dibutuhkan lulusan untuk memperoleh pekerjaan pertama setelah menyelesaikan studi di Program Studi Pendidikan Ekonomi FE UNY. Waktu tunggu lulusan ini diukur dalam satuan bulan.

Jenis pekerjaan adalah macam atau kategori pekerjaan yang ditekuni lulusan setelah menyelesaikan studi di Prodi Pendidikan Ekonomi FE UNY. Sementara itu tingkat relevansi adalah kesesuaian antara bidang pekerjaan yang sekarang sedang ditekuni lulusan dengan bidang keahlian yang dimiliki lulusan. Ukuran relevansi dilihat dari jenis pekerjaan bidang keguruan dan kewirausahaan. Sedangkan kinerja adalah unjuk kerja yang dimiliki 
lulusan setelah menekuni pekerjaan yang didapatkan. Kinerja lulusan diukur dari penilaian diri lulusan terhadap integritas, profesionalisme, kemampuan bahasa Inggris, penggunaan teknologi informasi, kemampuan komunikasi, kerjasama dalam tim, dan kemampuan pengembangan diri.

Populasi dalam penelitian ini adalah seluruh lulusan (alumni) dari Jurusan Pendidikan Ekonomi Fakultas Ekonomi Universitas Negeri Yogyakarta lulusan tahun 2007-2016. Sedangkan sampel diambil secara convenience sampling dengan memanfaatkan database lembaga tentang keberadaan alumni.

Pengumpulan data dilakukan dengan metode angket, dokumentasi, dan wawancara. Teknik analisis data yang digunakan adalah analisis deskriptif berupa tabulasi data, baik tunggal maupun tabulasi silang, dan visualisasinya dalam bentuk grafik. Analisis ini digunakan untuk melihat profil, persebaran dan kecenderungan setiap variabel dilihat dari berbagai karakteristik lulusan.

\section{HASIL DAN PEMBAHASAN}

Indikator pertama yang dijadikan acuan kualitas penyelenggaraan program studi adalah masa tunggu lulusan untuk memperoleh pekerjaan pertama setelah menyelesaikan studi. Semakin cepat lulusan mendapatkan pekerjaan pertama semakin baik penyelenggaraan program studi tersebut. Penelitian ini menemukan bahwa rentang masa tunggu lulusan untuk mendapatkan pekerjaan pertama berkisar antara 0-30 bulan dengan ratarata masa tunggu 3,07 bulan. Hal ini mengindikasikan bahwa masa tunggu lulusan untuk mendapatkan pekerjaan pertama termasuk dalam kategori cepat yakni sekitar 3 bulan. Bahkan 51 persen alumni mengaku sudah bekerja sambil studi. Hal ini menunjukkan bahwa lulusan Prodi Pendidikan Ekonomi FE UNY termasuk mudah untuk mendapatkan pekerjaan.

Rincian masa tunggu lulusan dapat dilihat di Tabel 1. Pada tabel tersebut ditemukan bahwa sebagian besar lulusan (53\%) mampu memperoleh pekerjaan kurang dari 1 bulan dan 26\%-nya mampu memperoleh pekerjaan antara 1-3 bulan, sedangkan lulusan yang masa tunggunya lebih dari 1 tahun hanya sekitar 3\%. Hal ini mengindikasikan bahwa lulusan Prodi Pendidikan Ekonomi FE UNY termasuk mudah terserap di dunia kerja.

Tabel 1. Masa Tunggu Lulusan

\begin{tabular}{lcrr}
\hline No & $\begin{array}{c}\text { Masa Tunggu } \\
\text { (bulan) }\end{array}$ & F & Persentase \\
\hline 1 & $<1$ & 72 & 52,9 \\
2 & $1-3$ & 35 & 25,7 \\
3 & $4-6$ & 16 & 11,8 \\
4 & $7-9$ & 5 & 3,7 \\
5 & $10-12$ & 4 & 2,9 \\
6 & $>12$ & 4 & 2,9 \\
\hline & Jumlah & 136 & 100,00 \\
\hline
\end{tabular}

Dilihat dari masa studi seperti terlihat di Tabel 2 ditemukan bahwa ada kecenderungan lulusan yang masa studinya pendek (4 tahun ke bawah) memiliki IPK yang lebih tinggi dibandingkan dengan lulusan yang masa studinya panjang (lebih dari 4 tahun). Hal ini menunjukkan bahwa masa studi lulusan memiliki pengaruh terhadap kecepatan lulusan untuk memperoleh pekerjaan yang pertama setelah lulus.

Namun demikian, jika dilihat dari nilai IPK ditemukan bahwa lulusan yang IPK-nya tinggi $(3,00$ ke atas) rata-rata masa tunggunya 3,12 bulan sedangkan lulusan yang IPK-nya rendah (kurang dari 3,00 ) memiliki rata-rata masa tunggu 2,44 bulan. Temuan ini menunjukkan bahwa tingginya IPK tidak menjamin lulusan untuk memperoleh pekerjaan yang lebih cepat. 
Tabel 2. Masa Tunggu Lulusan menurut Masa Studi dan IPK

\begin{tabular}{llr}
\hline No & \multicolumn{1}{c}{ Variabel } & $\begin{array}{l}\text { Rata-rata Masa } \\
\text { Tunggu (bulan) }\end{array}$ \\
\hline 1 & Masa Studi & \\
& $>4$ tahun & 2,861 \\
& $<=4$ tahun & 3,222 \\
2 & IPK & \\
& $<3,0$ & 2,444 \\
& $>=3,0$ & 3,115 \\
\hline & Total & 3,071 \\
\hline
\end{tabular}

Adapun perbedaan kecepatan memperoleh pekerjaan menurut jenis kelamin dapat dilihat pada Gambar 1. Untuk masa tunggu kurang dari 1 bulan, persentase lulusan laki-laki cenderung lebih banyak dari pada lulusan perempuan. Kondisi tersebut berbalik untuk masa tunggu antara 1-3 bulan. Sementara itu untuk masa tunggu yang lain cenderung memiliki proporsi yang sama. Hal ini menunjukkan bahwa secara keseluruhan tidak ada perbedaan masa tunggu antara lulusan lakilaki dan perempuan.

Salah satu tujuan utama penyelenggaraan prodi adalah menghasilkan lulusan yang mampu bersaing di dunia kerja bahkan diharapkan mampu menciptakan lapangan kerja bagi dirinya sendiri dan orang lain, begitu juga prodi Pendidikan Ekonomi FE UNY. Hasil penelitian ini ditemukan bahwa peluang kerja lulusan Prodi Pendidikan Ekonomi FE UNY cukup bervariasi, mulai dari dosen dan PNS sampai dengan buruh (lihat Tabel 3). Temuan ini menunjukkan bahwa lulusan Prodi Pendidikan Ekonomi FE UNY mampu bersaing dan terserap dalam dunia kerja dengan cukup memadai. Hal ini sejalan dengan hasil penelitian Kobstan (2005) yang menyatakan bahwa pendidikan dan keahlian seseorang memiliki peran yang penting dalam memperoleh pekerjaan. Keberhasilan seseorang dalam meraih

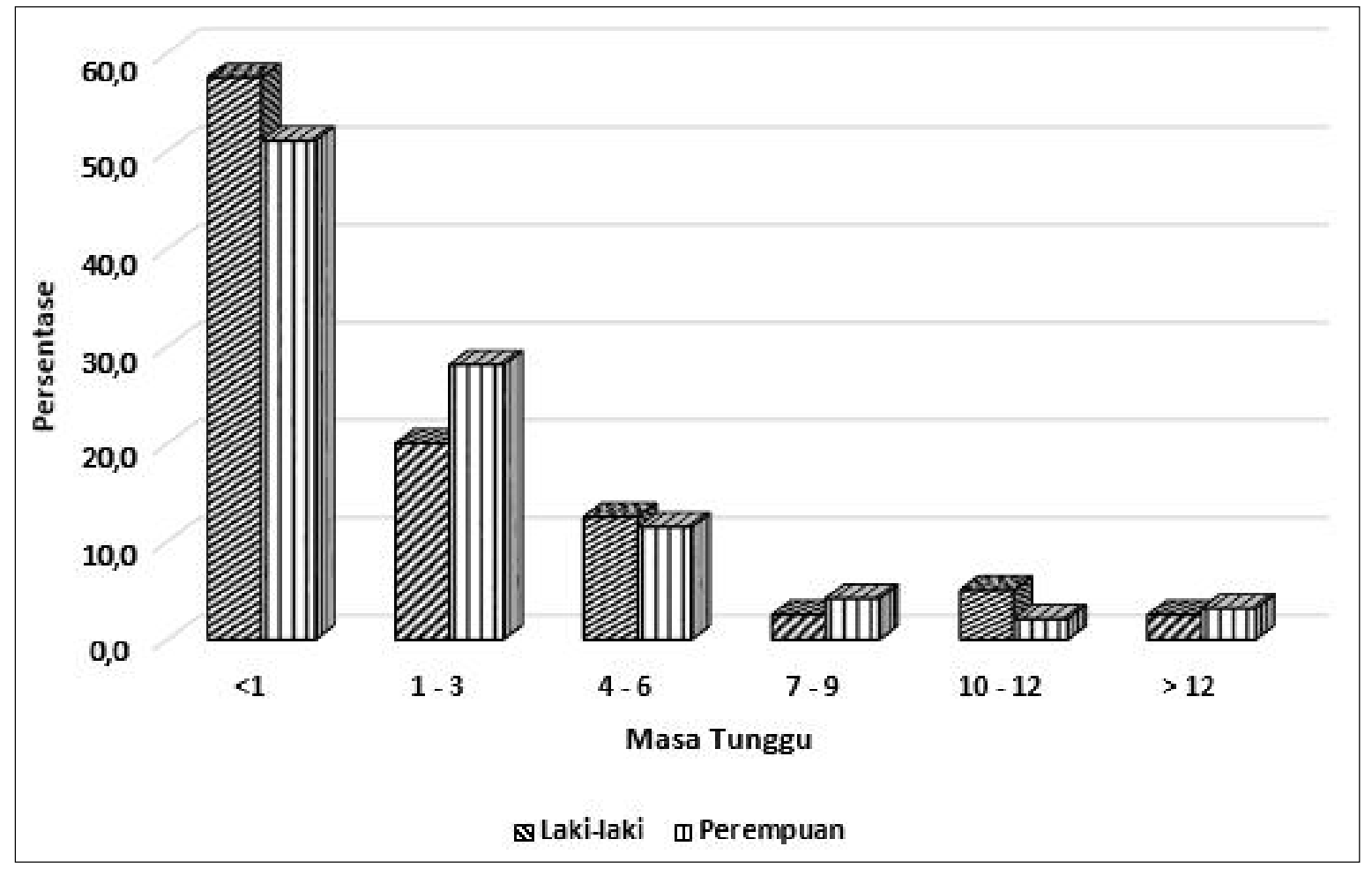

Gambar 1. Masa Tunggu Lulusan Menurut Jenis Kelamin 
Tabel 3. Profil Pekerjaan Pertama dan Sekarang

\begin{tabular}{llrrrr}
\hline \multirow{2}{*}{ No } & \multirow{2}{*}{ Jenis Pekerjaan } & \multicolumn{3}{c}{ Pekerjaan Pertama } & \multicolumn{3}{c}{ Pekerjaan Sekarang } \\
\cline { 3 - 6 } & & $\mathrm{F}$ & $\%$ & $\mathrm{~F}$ & \multicolumn{1}{c}{$\%$} \\
\hline 1 & Dosen & 1 & 0,7 & 5 & 3,7 \\
2 & PNS Guru & 4 & 2,9 & 10 & 7,4 \\
3 & Guru Swasta & 29 & 21,3 & 29 & 21,3 \\
4 & Tenaga Pengajar, tentor, dsb & 42 & 30,9 & 27 & 19,9 \\
5 & Pegawai Swasta & 41 & 30,1 & 40 & 29,4 \\
6 & Wirausaha & 7 & 5,1 & 9 & 6,6 \\
7 & Buruh & 1 & 0,7 & 1 & 0,7 \\
8 & Tidak Bekerja & 0 & 0,0 & 2 & 1,5 \\
9 & Lainnya & 11 & 8,1 & 13 & 9,6 \\
\hline & Jumlah & 136 & 100,0 & 136 & 100,0 \\
\hline
\end{tabular}

pekerjaan dan meniti karir dalam pekerjaan tersebut sangatlah tergantung pada tingkat pendidikan dan keahlian yang dimilikinya.

Penelitian ini juga menemukan bahwa profesi sebagai tenaga pengajar, tentor, pegawai swasta, dan guru swasta menjadi profesi pertama yang banyak menyerap lulusan, sedangkan dosen, PNS dan wirausaha penyerapannya sangat kecil. Hal ini mengindikasikan bahwa tenaga pengajar dan pegawai swasta tampaknya menjadi alternatif pertama peluang kerja yang menjadi bidikan lulusan.

Jika dilihat dari profesi sekarang ditemukan bahwa pegawai swasta tetap menempati proporsi yang paling banyak sebagai pilihan profesi lulusan. Namun demikian, ada pergeseran proporsi antara guru swasta dan tenaga pengajar/ tentor (lihat Gambar 2). Guru swasta tampaknya lebih menjadi pilihan profesi lulusan dibandingkan tenaga pengajar/ tentor. Begitu juga PNS guru dan dosen terjadi peningkatan persentasenya untuk pekerjaan sekarang dibandingkan dengan pekerjaan pertama lulusan. Hal ini mengindikasikan bahwa terjadi pergeseran pekerjaan pertama dan sekarang. Tentor/ tenaga pengajar di lembaga-lembaga bimbingan belajar tampaknya menjadi profesi alternatif bagi sebagian besar lulusan sebelum mendapatkan pekerjaan lain yang lebih menjanjikan seperti guru, dosen dan wirausaha.

Sesuai dengan tujuan Prodi Pendidikan Ekonomi FE UNY yakni menghasilkan pendidik dan wirausaha maka berdasarkan profesi yang menjadi pilihan lulusan, sebagaimana disajikan dalam Tabel 4, ditemukan bahwa sebagian besar lulusan (61\%) memiliki pekerjaan pertama yang sesuai dengan bidang keahliannya. Kesesuaian tersebut mengalami penurunan untuk pekerjaan sekarang menjadi 59\%. Pergeseran tersebut terjadi karena adanya pergeseran profesi lulusan.

Jika dilihat dari tahun lulus ditemukan bahwa ada untuk lulusan tahun 2007 dan 2008 memiliki tingkat kesesuaian pekerjaan baik pertama maupun sekarang yang sangat tinggi, yakni mencapai kisaran 90\%. Namun demikian, tren kesesuaian pekerjaan mengalami penurunan untuk lulusan tahun-tahun berikutnya (lihat Tabel 5 dan Gambar 3). Bahkan untuk lulusan tahun 2016 kesesuaian pekerjaan hanya mencapai 30-40 persen. 


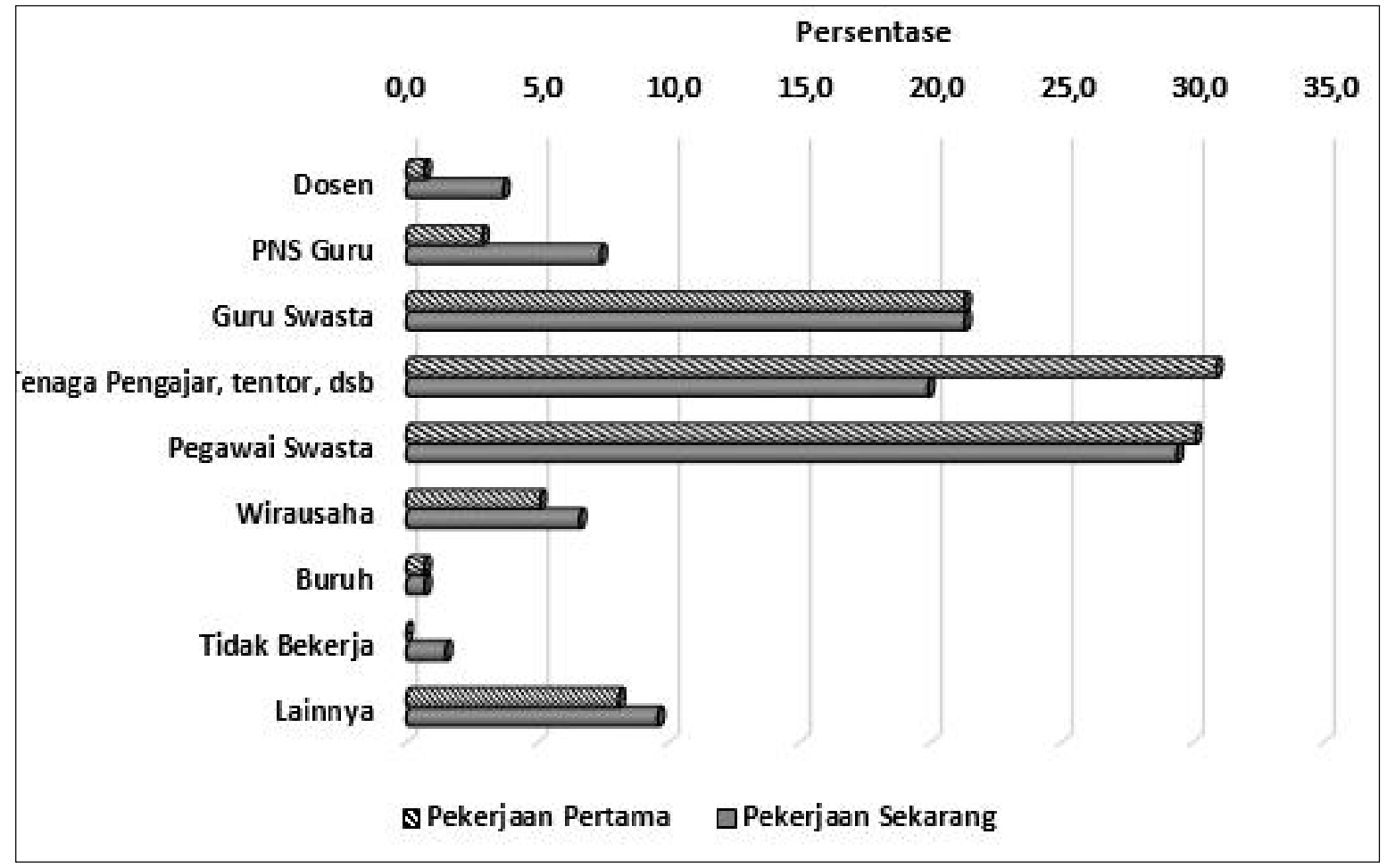

Gambar 2. Pekerjaan Lulusan (Pertama dan Sekarang)

Tabel 4. Profil Kesesuaian Pekerjaan Lulusan

\begin{tabular}{rlrrrr}
\hline \multirow{2}{*}{ No } & Relevansi & \multicolumn{2}{c}{ Pekerjaan Pertama } & \multicolumn{2}{c}{ Pekerjaan Sekarang } \\
\cline { 3 - 6 } & Pekerjaan & \multicolumn{1}{c}{ F } & \multicolumn{1}{c}{$\%$} & \multicolumn{1}{c}{ F } & \multicolumn{1}{c}{$\%$} \\
\hline 1 & Tidak sesuai & 53 & 39.0 & 56 & 41.2 \\
2 & Sesuai & 83 & 61.0 & 80 & 58.8 \\
\hline & Jumlah & 136 & 100.0 & 136 & 100.0 \\
\hline
\end{tabular}

Tabel 5. Profil Kesesuaian Pekerjaan Lulusan

\begin{tabular}{cccc}
\hline \multirow{2}{*}{ No } & Tahun Lulus & \multicolumn{2}{c}{ Kesesuaian Pekerjaan $(\%)$} \\
\cline { 3 - 4 } & & Pertama & Sekarang \\
\hline 1 & 2007 & 81.8 & 90.9 \\
2 & 2008 & 91.7 & 91.7 \\
3 & 2009 & 42.9 & 57.1 \\
4 & 2010 & 66.7 & 55.6 \\
5 & 2011 & 35.7 & 50.0 \\
6 & 2012 & 51.7 & 44.8 \\
7 & 2013 & 68.2 & 63.6 \\
8 & 2014 & 70.6 & 52.9 \\
9 & 2015 & 66.7 & 50.0 \\
10 & 2016 & 33.3 & 44.4 \\
\hline
\end{tabular}




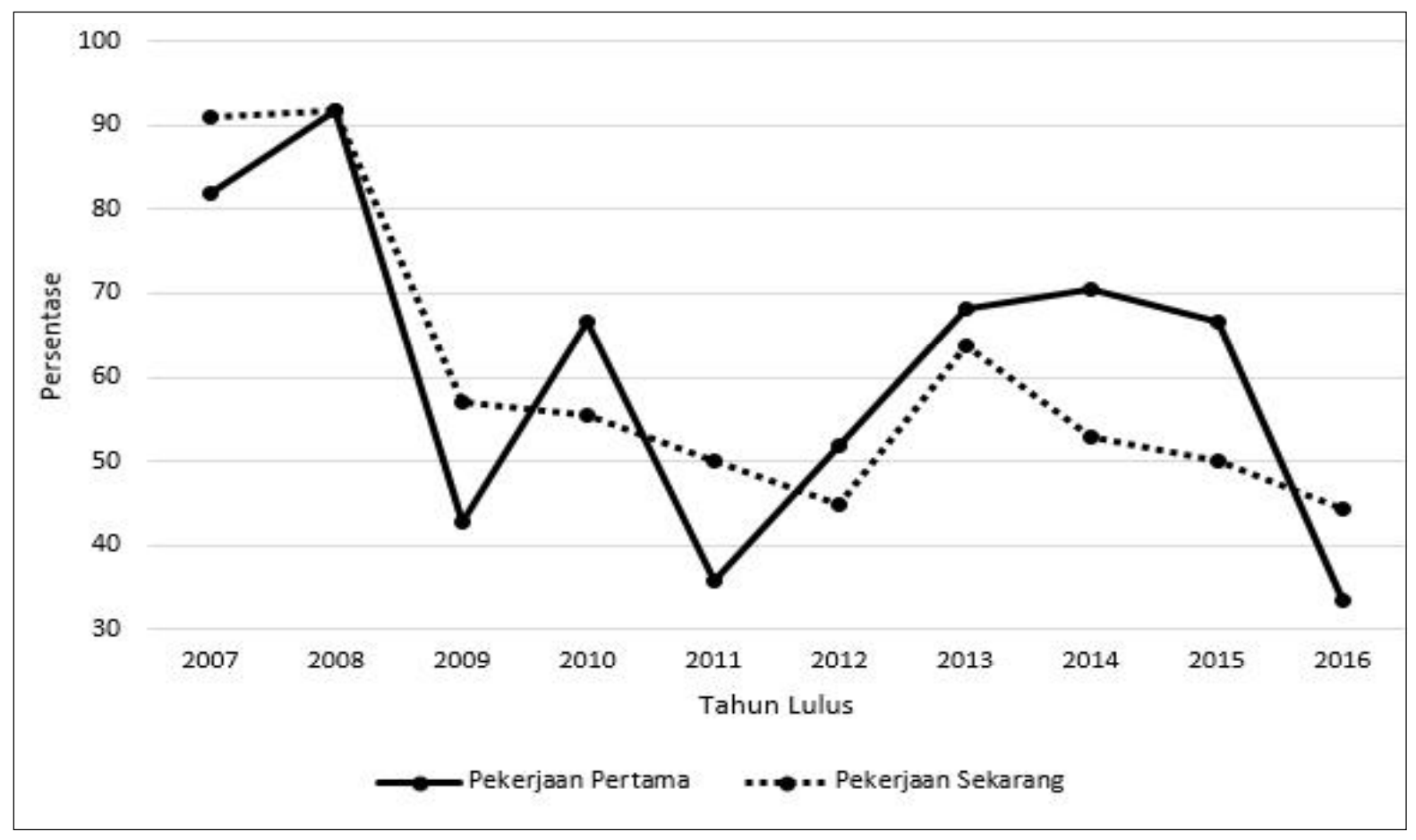

Gambar 3. Persentase Relevansi Pekerjaan menurut Tahun Lulus

Terkait dengan relevansi pekerjaan lulusan, beberapa hasil tracer studi yang dilakukan oleh peneliti lain juga menyatakan bahwa secara keseluruhan ada kesesuaian antara profesi yang ditekuni alumni dengan bidang keahlian yang dimiliki (Dewojati, dkk., 2002; Herlinah, 2000; Mulyadi; 2006, Muhson, dkk., 2012). Hal ini mengindikasikan bahwa konsep link and match yang sudah dikembangkan dalam dunia pendidikan tampaknya mampu dibuktikan dengan semakin banyaknya lulusan perguruan tinggi yang berkiprah dalam dunia kerja yang sesuai dengan bidang keahliannya. Hal ini tidak lepas dari kurikulum yang diterapkan di perguruan tinggi yang secara periodik dilakukan pengkajian dan pengembangan agar mampu memenuhi kebutuhan dan tuntutan dunia kerja.

Temuan tersebut mengindikasikan bahwa tantangan lulusan ke depan semakin berat untuk mendapatkan profesi pekerjaan yang sesuai dengan bidang keahlian. Persaingan kerja menjadi semakin ketat karena semakin banyaknya lulusan yang memiliki bidang keahliannya yang sama sementara jumlah kesempatan kerja semakin lama semakin terbatas. Oleh karena itu, lulusan perlu diberikan bekal yang cukup memadai untuk dapat bersaing di dunia kerja.

\section{SIMPULAN}

Lulusan Prodi Pendidikan Ekonomi FE UNY termasuk mudah terserap di dunia kerja. Masa tunggu lulusan untuk mendapatkan pekerjaan pertama termasuk dalam kategori cepat yakni dengan rata-rata 3 bulan. Peluang kerja lulusan terbesar untuk pekerjaan pertama masih didominasi oleh pegawai swasta, tenaga pengajar/tentor, dan guru swasta. Untuk profesi pegawai swasta dan guru swasta masih menjadi pilihan profesi sekarang sementara profesi tenaga pengajar/tentor bergeser ke PNS, baik sebagai guru maupun dosen. 
Relevansi lulusan dengan pekerjaan yang ditekuni saat ini tergolong cukup baik karena hanya $61 \%$ lulusan bekerja sesuai dengan bidang keahliannya. Kinerja lulusan termasuk dalam kategori baik. Lulusan memiliki keunggulan dalam hal integritas, penguasaan teknologi informasi, kemampuan bekerja sama dengan tim, kemampuan berkomunikasi, kemampuan profesional, dan kemampuan untuk melakukan pengembangan diri. Hanya kemampuan Bahasa Inggris yang masih dalam kategori cukup.

Sesuai dengan kesimpulan tersebut, beberapa implikasi yang penting yang dapat diambil adalah program studi Pendidikan Ekonomi diarahkan untuk mencetak tenaga profesional yang mampu menjalankan perannya sebagai guru ekonomi baik di tingkat SLTP maupun SMA, oleh karenanya perlu diperbanyak pengalaman praktik sehingga akan lebih menambah pengalaman alumni untuk terjun sebagai tenaga pengajar dalam dunia kerja. Sangat penting untuk membangun jaringan baik dengan instansi swasta maupun pemerintah, ini dimaksudkan sebagai salah satu sosialisasi kemampuan yang dimiliki lulusan Program Studi Pendidikan Ekonomi, sehingga instansi terkait tersebut dapat menjadi salah satu instansi yang menjadikan lulusan Prodi Pendidikan Ekonomi sebagai tenaga yang bisa mereka serap.

\section{DAFTAR PUSTAKA}

Badan Pusat Statistik. 2014. Klasifikasi Baku Jenis Pekerjaan Indonesia KBJI 2014. Jakarta: Kementrian Ketenagakerjaan dan Badan Pusat Statistik.

Citradewi, A., \& Margunani. 2016. "Pengaruh Kepribadian, Pendidikan Kewirausahaan, dan Lingkungan Keluarga terhadap Aktivitas Berwirausaha Mahasiswa Universitas
Negeri Semarang". Economic Education Analysis Journal, 5(2), 519-531.

Dewojati, D., dkk. 2002. "Peta Alumni Program Studi Pendidikan Seni Kerajinan FBS Universitas Negeri Yogyakarta pada Dunia Kerja". Laporan Penelitian. Yogyakarta: FBS UNY.

Herlinah. 2007. "Penelusuran Alumni Jurusan Pendidikan Seni Tari Tahun 2000-2006". Laporan Penelitian. Yogyakarta: FBS UNY

Kobstan, D. W. 2005. "Pengaruh Latar Belakang Demografi terhadap Kecepatan Memperoleh Pekerjaan di Sektor Perdagangan dan Industri di Semarang". Bachelor thesis. Petra Christian University.

Kusnendi. 2003. Ekonomi Sumber Daya Manusia dan Alam. Jakarta: Universitas Terbuka.

Muhson, A., Wahyuni, D., Supriyanto, \& Mulyani, E. 2012. "Analisis Relevansi Lulusan Perguruan Tinggi dengan Dunia Kerja". Jurnal Economia, 8(1), 42-52.

Mulyadi, dkk. 2006. "Studi Penelusuran Alumni (Tracer Study) Program Studi S1 Pendididikan Luar Sekolah Fakultas Ilmu Pendidikan Universitas Negeri Yogyakarta". Laporan Penelitian. Yogyakarta: FIP UNY.

Simanjuntak, P. J. 1998. Pengantar Ekonomi Sumber Daya Manusia. Jakarta: Fakultas Ekonomi Universitas Indonesia.

Sudjana, S. 2004. Penelitian dan Penilaian Pendidikan. Bandung: Sinar Baru Algesindo.

Sukirno, S. 2000. Ekonomi Pembangunan Proses, Masalah dan Dasar Kebijakan Pembangunan. Jakarta: UI-Press.

Sumardiningsih, S., Sukidjo, Muhson, A., \& Hafidh, A. A. 2016. "Analysis of Human Resources Investment in 
Economics Education Study Program". Proceeding of International Symposium on the Transition from School to Work. Yogyakarta: Universitas Negeri Yogyakarta, 14-21.

Tempo. 2016. "BPS: Pengangguran Terbuka di Indonesia Capai 7,02 Juta Orang". Tempo Online. Diunduh dari https://m.tempo.co pada tanggal 23 Maret 2017.
Wahyuni, D., dkk. 2014. "Daya Saing, Tingkat Keterserapan, dan Relevansi Lulusan Pendidikan Ekonomi FE UNY dalam Dunia Kerja". Laporan Penelitian. Yogyakarta: FE UNY

Yoon, J., Han, N. C., \& Seo, Y. J. 1996. "Sense of Control Among Hospital Employees: An Assessment of Choice Process, Empowerment, and Buffering Hypotheses". Journal of Applied Social Psychology, 26(8), 686-716. 